\title{
A REVIEW AND ANALYSIS OF EXISTING LEGAL AND POLICY ISSUES RELATED TO LAND TENURE AND AGRICULTURE IN NEPAL
}

\author{
Sharma, K.*, Khanal, S. N. \\ Department of Environmental Science and Engineering \\ School of Science, Kathmandu University \\ *Corresponding address: keshav.sharma@practicalaction.org.np \\ Received 31 May, 2010; Revised 19 September, 2010
}

\begin{abstract}
This review takes stock of current legislative provisions and policies pursued by the Government of Nepal with regard to agriculture and land tenure. Currently, land tenure issues are primarily governed under the legislations enacted by the Ministry of Land Reform and Management, while there are a number of policies formulated in order to facilitate agricultural production by the Ministry of Agriculture and Cooperatives, Ministry of Water Resources for irrigation regulation, Ministry of Forest and Soil Conservation through Leaseholds forestry programme.
\end{abstract}

The Government of Nepal has already amended the Land Act, 2021 B.S. twice. Each amendment has targeted something other than ceilings. Amendments in regulation and devising other sectoral policies have not adequately discussed nor have encouraged sustainable land management. New and innovative policies are required to prevent degradation and achieve sustainable management of the precious land resource base of the country.

\section{BACKGROUND}

Land can be considered the most important resource in Nepal. Livelihood of more than 80 percent of the population depends on agriculture, and hence land. Of the total land suited for agriculture, nearly $65 \%$ or so accounts for rainfed agriculture. The piece of land possessed by ascend the parental land property division is the predominant practice of land tenure in all parts of the country. This can be regarded as one of the several causes of land fragmentation to the smallest size whereby the land could be gradually marginalized due to continued fragmentation.

The formal land entitlement in Nepal is a relatively recent endeavor since the country promulgated a Civil Code. Until the 1960s, land was held under various forms of tenure, such as raikar, birta and guthi or under the customary kipat system. Formal administration was carried out by local level state officials (tharis and subbas). Beginning in 1960, the then political administration began to replace the traditional system of land administration with laws such as Birta Abolition Act 1959 A.D., followed by the promulgation of the Civil Code 1963 A.D, and the Land Administration Act 1967 A.D.

The Land Act, 1964 aims to divert 'inactive' capital and labor from land to other economic sectors, bring about an equitable distribution of cultivable land, improve the standard of living of 'actual tillers' who depend on land for their livelihood, and maximize agriculture production(preamble). This Act abolishes the zamandari system of land ownership (section 3). Ceilings on ownership are specified in section 7 and vary according to geographical location. 
The maximum size of an agriculture holding is 6.6 hectares, while the largest homestead may cover 0.66 hectares (section 7). Land in excess of these ceilings is to be acquired by the 'prescribed authority' (section 15) upon payment of compensation (section 19). The land so acquired may be sold or reallotted (section 21) and, until the sale or reallotment is finalized, may be "given away" for cultivation on "any terms" to the former landowner or tenant, or any other person (section $21 \mathrm{~A}$ ). Such land is to be distributed among Dalits, members of ethnic communities and bonded labourers who have been freed, with priority given to the residents of the Village Development Committee (VDC) or municipality in which the land has been confiscated (section 21, as amended in 2002).

Exemptions on these ceilings may be granted in the case of land held by the government itself, or by industries, or educational and medical institutions (section12). Other types of holdings that may also be exempted from ceilings include land held by District Development Committees (DDCs), VDCs or municipalities (section 12 (b)); land used "under prescribed conditions for agriculture purposes" as prescribed by the government (section 12 (e)); land under the jurisdiction of the guthi corporation (section 12 (f)); and land held by cooperative agriculture societies (section $12(\mathrm{~g})$ ).

Tenancy in land was abolished from 1996 by means of the Fourth Amendment to the Act (section 25 (2)). The amendment allows tenants to retain 50 percent of the land they were previously farming or occupying, or to accept a cash payment based on the current value of the land to which the tenant is entitled (section $26 \mathrm{D}$ ). A unique feature of the Lands Act is a provision on compulsory crop savings (section 40) which has not been applied in practice since the adoption of the Land Revenue Act 1977.

The Land (Survey and Measurement) Act stipulates that land may be registered on the basis of an unofficial deed if it has been in the uninterrupted possession of an individual for 15 years (section 6 (5a)). This provision is only enforceable in the case of individual practice or possession.

\section{THE PRESENT CONTEXT}

The Land Act and Rules 1964, authorize the government to implement a programme for control of land fragmentation and consolidation of land. This Act also allows for undertaking cooperative farming to a group of ten or more landowners by increasing facilities over agricultural tools, improved agriculture technology, fertilizer, seeds, irrigation facility, and electricity, etc. It provides the procedures for consolidation of land and authorizes the government not to allow fragmentation below a certain unit of land in the area where the programme for control of fragmentation and consolidation of land has been initiated. However, the implementation of this Act is as yet minimal.

The land reform programme was introduced with the aim of diverting idle capital from land to other areas of economic activities and initiates a process of industrialization in the country. There was a great hope that with the ceiling on landholding in place a large amount of land would be available for redistribution. Because of the slow, delayed and weak implementation of the Act the result was nominal. Ceiling on land holding meant very little. The plan to have a large chunk of excess land above the legal ceiling simply did not materialize. 
The amendment to the Land Act in 2058 B.S. revising the ceiling and bringing it further down once again (to 11 bighas $^{1}$ from 28 bighas) aimed at redistributing excess land above the ceiling. It would have benefited landless persons such as bonded labourers, Dalits, the indigenous communities and Janajatis. But it again failed to materialize as was the case before. There was simply no excess land available. Both these efforts may be called "land reform in law" hither to. Land reform is limited to land administration. A real phase of land management has yet to be put into effect. There is one more problem added to the land ceiling, however. The recent wave of protests in the Terai against the hill people was the protest against the ceiling on landholdings which is unequal in terms of value of the land. The land holding ceiling in the Terai, which is limited to 11 bighas is of far less value than land in Kathmandu or in other urban areas.

The amendment introduced to the Act in 2053 B.S. for doing away with the dual ownership of land to boost agricultural production has set a stage for moving towards the principle "land to the tiller". The amendment, however, remains to be implemented effectively due partly to the unstable political situation in the country. Effective implementation of this reform measure requires large amounts of financial resources, and a Land Bank to accompany the reforms. In fact "land management" is what the people really need.

The National Agriculture Policy of 2004 A.D. gives special priority to a pocket of high-value agricultural products. The local bodies are to delegate the formulation, implementation and monitoring of the agricultural plans. The policy also gives emphasis about the mobilization of farmers' group for managing on-site extension services. Likewise, the role of resource centers has been foreseen to producing local seeds, seedlings, plants and hybrids. Such centers would gradually integrate and operate surveys/surveillance and laboratory services in such fields (e.g. soil analysis, seed certification, crop protection and livestock diagnosis). Also the policy emphasizes flow of agricultural credit is to the similar returns of production and enterprises.

Special facilities for target groups (oppressed, depressed classes, marginal farmers, and agricultural workers) will be developed through creating opportunities of gaining lands and contractual farmlands. For the purpose of upgrading forests and other lands and providing support to the task of alleviating poverty, marginal lands, pastures, degraded forests and barren public lands will be handed over to the target communities under the lease agreements for being used according to the feasibility, as farms to cultivate crops as grass, fodder, agro-forests, medicinal herbs and silk or as horticultural farms.

The policy also seeks to develop commercial and competitive farming system by enhancing a gradual extension of livestock insurance program and organic farming and certification, regulated distribution of manure, insecticides, pesticides and laboratory services and its accreditation. Further, the systematization of livestock quarantine and updates of regulatory services is some essential and important aspects of the policy. Local participation and mobilization has been key to monitor and regulate quality standards of foodstuffs. However, priority will be focused onto the cooperative based agricultural industries.

\footnotetext{
${ }^{1} 1$ hactare equals to 1.5 bigha
} 
Conservation, promotion and proper utilization of natural resources and the environment can only be achieved through promoting agro-forestry systems to improve degraded forests and natural reservoirs. The local bodies are to consult in consolidating plots and checking the fragmentation of the cultivable lands. This can thus be achieved through managing land cooperatives/partnership/group basis by making necessary legal provisions to achieve the intended goals.

Implementation and monitoring arrangements need to follow a participatory approach in the process. At national level, the establishment of a National Agricultural Development Board help monitor programs in a participatory and coordinated manner. Local government entities such as CDC and DDC must be made responsible for formulation, implementation, monitoring and evaluation of plans in accordance with the self-governance act. A District Agricultural Development Committee and Village Agricultural Committee formed at district and village levels respectively should assist local bodies in implementing and monitoring the policies.

\section{MAJOR ISSUES}

Land, the supply of which at any given time is limited, is a scarce resource. The issue, therefore, should be proper utilization and sustainable management of the land. Land is the principal factor for development in agriculture sector. It is the most important factor of production. "Intensive agriculture" through year-round irrigation is a potential means of enhancing agriculture development. However, this is not feasible across the entire country. Agricultural development plays a central role in land degradation and sustainable rural livelihood in Nepal. The problem of declining productivity and deterioration of land resource base is particularly serious in rainfed areas where marginal farming and extended fallow period are widespread. Implementation of land management related policy remains a weak in Nepal. As, there is no separate law to address agriculture land degradation, many sectoral laws and programme policies provide the legal context relating to sustainable land management through soil conservation, fertility management and conservation agriculture.

\section{Implementation of International Conventions}

In the wake of combating desertification, Nepal has endorsed the United Nations Convention on Desertification (UNCCD) on January $13,1997^{2}$. Besides that Nepal is also a party to Convention on Biological Diversity (CBD), 1992. A total of 17 pressing environmental issues have been documented in Nepal, the land degradation and desertification have been prioritized as the most urgent and moderately urgent issues needing immediate program implementation ${ }^{3}$. Ministry of Environment, Science and Technology has prepared a National Action Plan (NAP) 2002 which has documented a number of activities to be performed to combat land degradation through soil conservation, agro forestry, capacity building and by addressing cross cutting issues.

However, supply of irrigation water is again limited due to geographical as well as technoeconomic resource factor. Nepal's area under irrigated agriculture is still very low in spite of abundant average flow of water. But water is not available everywhere and at a time when

\footnotetext{
${ }^{2}$ His Majesty's Government Ministry of Population and Environment, April 2002, Nepal Second National Report for first session of the committee for the review of the implementation of the UN Convention to Combat Desertification, Kathmandu

${ }^{3}$ His Majesty's Government, Ministry of Environment and Population (1998), State of the Environment Nepal, Singh Durbar, Kathmandu, Nepal
} 
needed. The hills and mountain have limited irrigable land. More focus is needed on research and development of "dry crops". It will also address food security. Management, therefore, and not supply where the attention is needed.

\section{Amendments to the Land Act 2019 B.S.}

Though a number of amendments in the Land Act introduced over the years, the law now is in place for the management of land. The Land Act has now provisions to deal with issues like consolidation of land, control of fragmentation, land use zoning, and cooperative farming. The Land (Measurement) Act, 2019 and Rules 2058 talks about classification of land in terms of their uses such as agricultural, commercial or residential. Furthermore, the government is authorized to arrange for measurement of private, government or public land for the purpose of consolidation of land or integrated development of land.

All these concerns are cross-cutting issues and require coordination mechanisms. Several ministries are involved including the Ministry of Land Reform and Management (MoLRM), MoFSC and MoAC. End user of land is the MoAC. It should play a proactive role in organizing coordination mechanisms covering various areas of activities. The joint approach such as the Leasehold Forestry and Livestock Programme coordinated by two departments is an example.

The Land (Measurement) Act, 2019 B.S. and Rules, 2058 B.S. provides the basis for land classification while taking measurement of the area, the land was classified in terms of their uses, agricultural and commercial or residential. This enables the government arrange for measurement of private, government or public land for the purpose of consolidation of land or integrated development of the land. However, the implementation of this Act is continuously ignored while government authorizes the private sector be involved in transforming agricultural land into haphazardly made town planning.

\section{Other factors affecting land use}

A number of other issues and factors influence the utilization of the land. Irrigation water plays an important role for optimizing the use of agricultural land. The fallow period is generally extends to 4-5 months in rainfed agriculture systems. Since there is no any crop or crop residues in the field in this time period, the soil continues to loose its moisture and thus resulted into more compaction in its physical form. The performance of large public irrigation system is not satisfactory because of huge capital investment and users inability to run them on the tax generated by it. Irrigation policy, 2003 has tried little to be away from the conventional approach of irrigation systems by emphasizing on the build of water reservoirs, rainwater harvests and ground water resources as supplementary sources to the seasonal rainfall for managing year round irrigation. Besides, drip irrigation in few places no option has been developed in this regard to optimize the land use management for fallow period management and agriculture led poverty reduction.

Seed is one of the major inputs for agriculture production. Adequate and quality seed is perhaps more importance than other requisites of agriculture and has been realized as the farmers' rights. Protection of farmers from the increasing threat of losses of local land races could be headway towards spearheading sustainable agriculture production. As with the expanded global market, Genetically Modified Organisms (GMOs) continue to ruin the local breeds and cause them to disappear from the access of farmers. The Seeds Act, 2045 and Rules, 2054 has the provision to 
ensure the quality, minimum limit of the capacity of germination or purity of seeds, restricts on the use and sell of unidentifiable and restricted seeds. This Act enables the government to constitute a National Seeds Board to coordinate production and distribution of seeds both in public and private sectors, reserves the right for the issuance of license for import and export of seeds. This ct has granted the rights to breeder of new seeds so the property right of breeder can be preserved. As per the provision given in the Act certain species or breed of seeds essential for agriculture as for the purpose of regulating their use can be classified in as "designated seeds" and restricts the selling of the designated seeds of the species or breed of which is not identifiable or do not fulfill the minimum condition about germination or purity should be well defined and precisely listed.

Information on soil quality is hardly available for all agro-ecological zones. Rainfed agriculture systems are generally considered as nutrient deficient soils as long fallow period, grazing between the crops; complete removal of crop residues from the field is often practiced. Because of high rainfall in short period indicates that the soils may have acidic characteristics in rainfed agriculture systems. Regularly decreasing crops yield is the only reason to believe that the quality of soils is poor. Use of NPK fertilizer shows a big discrepancy between national averages of $35 \mathrm{~kg}$ versus $300 \mathrm{~kg}$ per hectare at the farm level. This resembles "too low" and "too high" fertilizer use trends, which does not seem to be sustainable in either direction. The Chemical Fertilizer (Regulatory) Order 2055 regulates the provisions and procedures for imports, manufacture or mixing, quality control and penalties.

\section{Fertilizer Policy and APP}

National Fertilizer Policy, 2002 aims to provide the fertilizers at concessionary rates to target population, however the implementation is not seen at all. To balance the environmental hazard of chemical fertilizer, NFP emphasizes to promote Integrated Plant Nutrients to achieve the level of fertilizer of $131 \mathrm{~kg}$ per hectare by the year 2014. This can be achieved only if on-farm nutrient and composting is promoted.

Under the Agriculture Perspective Plan (APP), priority has been given to soil fertility research and extension particularly through integrated plant nutrient management systems (IPNMS) that incorporate both organic and inorganic fertilizers (Ministry of Agriculture, 2002). Agriculture Perspective Plan Support Programme has been implementing in 25 districts declared as the districts majority of the population living below poverty line. The major portion of the support, as demanded by the CBOs, is largely given for the livestock, yet soil management activities are nominal under this programme. A sincere thrust is required to change the behaviors of the people to go with soil fertility or to harness the optimal benefit from raising livestock by properly managing urine and dung as supplemental soil nutrients.

According to the Chemical Fertilizer Regulatory Order, Fertilizer Board advises the government in the formulation of the policy, priorities, specifications, and quality control. The Order brings into operation a system of quality control at two levels, before the entry of fertilizers into the country, and at the point of distribution. It enables MoAC to designate any official or Inspector for the purpose of monitoring the sale of fertilizers to maintain quality. The inspector has authority to develop monitoring procedures include drawing of samples for analysis or even seize the fertilizer when he has reason to believe that the fertilizer traded is not of quality. 


\section{Pesticides}

Pesticides Act 2048 and Rules, 2050 which require to understand the role and responsibility of Pesticide Committee to advise the government for formulation of policy, setting quality standards of pesticides, production and use of pesticides through the requirement of quality standards, establishment of Pesticides Registration Agency, obligatory permission for the import, sale and use of pesticides by Pesticides Registration Agency's. Person as a professional sprayer should require permit with validity up to five years. This act provides for publish of approved list of pesticides in Nepal Gazette. The pesticides committee shall cancel or suspend registration of pesticides provided that they are ineffective or harmful to people or animals or environment. The role, as granted by the act, of Pesticides Inspector is equally important in hearing and deciding on the case.

\section{Land Reform}

As there is increasing understanding for about the use of biological substances and process for reclaiming the degraded soils, farmers' rights cannot be ignored for accentuating the environmental performance of agriculture. Rationally, the farmers are the key stakeholders at ground level and their deeds and doings play a substantive background to control agriculture emissions of greenhouses gases.

To reverse land degradation processes require appropriate incentives and actions to change the behavior of land users - principally farmers. Government policies are the major instruments to influence the behavior of land users at local and national levels through incentives and sanctions.

\section{FUTURE PRIORITIES AND NEEDS}

The issue of land tenure remains a contentious one in Nepal. The primary attention given to the land sector is often of distribution or redistribution of pieces of land. Nepal has had some major reforms in this regard before; however; the problem associated with land has been taking many forms. This is not because land is less productive or people are too poor to mamize benefits from the land, rather it is becoming more of a political issue that either perceived less or more without clear.

The growing food insecurity has opened up many fronts in relation to usage of lands. Government plans to implement Land Management Policy and Food Security Policy-if implemented-they may pave the way for coordinated land management activities. Equally significant, the Scientific Land Reform Commission could be another important endeavor in this regard.

\section{CONCLUSION AND RECOMMENDATIONS}

Institutions and stakeholders involved in the development of land resource management priorities, action plans and policies are scattered in different ministries and institutes. The flow of information among government agencies associated with land management is often irregular and or an ad hoc basis. There is also poor availability, accessibility and relevance of information flowing between the government and the private-I/NGO sectors, grass-roots institutions and farming communities due to lack of common platforms and regular mechanisms for information sharing on issues relating to policy and development. Presently the country lacks systematic and integrated land management and soil fertility management policies based on land capability, 
appropriate technology and crop sound for developing suitable nutrient management and enhanced agriculture production.

Scientific Planning and policy making for sustainable land management is a complex process because of their interaction of diverse sectors. The complexity of land management sector calls for a holistic approach to translating land management policies into administrative and management actions. The issues are multidimensional and interrelated, and therefore require a mix of integrated strategies. Guidance must come from the policy statements and translated into operational plans that help implementation of land management activities. The existing policies need to be simplified, harmonized and brought in line with other policies. This requires an interdisciplinary and inter-institutional /ministerial collaboration, co-ordination and participatory policy-making process that adequately and regularly links field level information to policy decision making.

The present analysis reveals that policy-making processes are highly complex. Political, social and economic circumstances influence the policy making process and determine the policy outcome. As the Government of Nepal is intent on the formulation of Scientific Land Reform Commission, the following points may be worth consideration:

- Such a commission should ensures inclusion of social, political and economic circumstances which influence and limit the effectiveness of the policy making process;

- It should take into consideration specific problems of rainfed agriculture and sustainable utilization of fragmented land to address food insecurity and access to land;

- It must create a proper synergy to link many of the scattered policies among the concerned ministries.

\section{REFERENCES}

1. EPC1993. Nepal Environmental Policies and Action Plan, Kathmandu, Environmental Protection Council, HMG, Nepal.

2. MOPE, 2002, HMG Ministry of Population and Environment, Second National Report for first session of the committee for the review of the implementation of the UN Convention to Combat Desertification, Kathmandu, Nepal.

3. MOPE and UNEP, 2004. Ministry of Population and Environment and United Nations Environment Program. Initial National Communication to the Conference of the parties of the United Nations Frame Work Convention on Climate Change.

4. NPC 1995. Agriculture Perspective Support Plan. National Planning Commission, HMG, Singha Durbar, Kathmandu, Nepal

5. NPC1997. The Ninth Five Year Plan (1997-2002). HMG, National Planning Commission, Kathmandu, Nepal. 
6. NPC 2002. The Tenth Five Year Plan (2002-2007)/Poverty Reduction Strategy Paper (PRSP). HMG, National Planning Commission, Kathmandu, Nepal.

7. NPC/IUCN. 1991. A Legislative and Institutional Framework for Environmental Management in Nepal. Review of legislation, administration procedures and institutional arrangements relating to land use and resource management. National Conservation Strategy Implementation Project,

8. National Planning Commission, HMG, Nepal in Collaboration with IUCN- The World Conservation Union, Kathmandu, Nepal.

9. Moore, P. and Pastakia, F. (Editors) 2007. Environmental Justice and Rural Communities: Studies from India and Nepal, IUCN, Bangkok, Thailand and Gland, Switzerland. xxvi+144 pp.

10. Subedi, A, Holt G., and Garforth, C. 2002. Working Paper 1: 'Review of Land Management Policy in Nepal'. Developing supportive policy environments for improved land management strategies - Nepal, LI-BIRD, Pokhara, Kaski, Nepal. 